\title{
The Deviation between Dairy Cow Metabolizable Energy Requirements and Pasture Supply on a Dairy Farm Using Proximal Hyperspectral Sensing
}

\author{
Federico Duranovich ${ }^{1, *(\mathbb{D})}$, Nicolás López-Villalobos ${ }^{1} \mathbb{D}$, Nicola Shadbolt ${ }^{1} \mathbb{D}$, Ina Draganova ${ }^{1}$, Ian Yule ${ }^{2}$ and \\ Stephen Morris ${ }^{1}$ (D) \\ 1 School of Agriculture and Environment, College of Sciences, Massey University, Private Bag 11-222, \\ Palmerston North 4442, New Zealand; N.Lopez-Villalobos@massey.ac.nz (N.L.-V.); \\ N.M.Shadbolt@massey.ac.nz (N.S.); I.Draganova@massey.ac.nz (I.D.); S.T.Morris@massey.ac.nz (S.M.) \\ 2 Massey AgriFood Digital Lab, School of Food and Advanced Technology, College of Sciences, Massey \\ University, Private Bag 11-222, Palmerston North 4442, New Zealand; I.J.Yule@massey.ac.nz \\ * Correspondence: F.N.Duranovich@massey.ac.nz
}

\section{check for} updates

Citation: Duranovich, F.; López-Villalobos, N.; Shadbolt, N.; Draganova, I.; Yule, I.; Morris, S. The Deviation between Dairy Cow Metabolizable Energy Requirements and Pasture Supply on a Dairy Farm Using Proximal Hyperspectral Sensing. Agriculture 2021, 11, 240. https://doi.org/10.3390/ agriculture 11030240

Academic Editor: Tomas Norton

Received: 16 February 2021

Accepted: 10 March 2021

Published: 12 March 2021

Publisher's Note: MDPI stays neutral with regard to jurisdictional claims in published maps and institutional affiliations.

Copyright: (c) 2021 by the authors. Licensee MDPI, Basel, Switzerland. This article is an open access article distributed under the terms and conditions of the Creative Commons Attribution (CC BY) license (https:/ / creativecommons.org/licenses/by/ $4.0 /)$.

\begin{abstract}
This study aimed at determining the extent to which the deviation of daily total metabolizable energy $\left(\mathrm{ME}_{\mathrm{t}}\right)$ requirements of individual cows from the metabolizable energy (ME) supplied per cow (DME) varied throughout the production season in a pasture-based dairy farm using proximal hyperspectral sensing (PHS). Herd tests, milk production, herbage and feed allocation data were collected during the 2016-2017 and 2017-2018 production seasons at Dairy 1, Massey University, New Zealand. Herbage ME was determined from canopy reflectance acquired using PHS. Orthogonal polynomials were used to model lactation curves for yields of milk, fat, protein and live weights of cows. Daily dietary ME supplied per cow to the herd and ME requirements of cows were calculated using the Agricultural Food and Research Council (AFRC) energy system of 1993. A linear model including the random effects of breed and cow was used to estimate variance components for DME. Daily herd $\mathrm{ME}_{\mathrm{t}}$ estimated requirements oscillated between a fifth above or below the ME supplied throughout the production seasons. DME was mostly explained by observations made within a cow rather than between cows or breeds. Having daily estimates of individual cow requirements for $\mathrm{ME}_{\mathrm{t}}$ in addition to ME dietary supply can potentially contribute to achieving a more precise fit between supply and demand for feed in a pasture-based dairy farm by devising feeding strategies aimed at reducing DME.
\end{abstract}

Keywords: metabolizable energy balance; pasture-based dairying; individual milking cows

\section{Introduction}

Supply of metabolizable energy (ME) from herbage has been identified as a major factor limiting performance of cows in pasture-based dairy farms [1,2]. In most pasturebased dairy farms, allocation of herbage and other feeds is calculated on a dry-matter basis, where assumptions are made about the ME content of the diet and the total ME required of the herd in order to achieve performance targets while maintaining low cost [3]. In contrast, more intensive indoor dairy farms using total mixed ration (TMR) feeding, require accurate measurement of dietary $\mathrm{ME}$ to feed cows diets that are more balanced to their actual energy requirements and dilute cost by improving productivity and feed conversion efficiency [4,5].

The use of recent advances in precision technology to measure herbage mass (HM) and herbage nutritive value (NV) has been proposed as a means of improving the efficiency of grazing and the use of feeds on extensive pasture-based dairy farm systems [6,7]. It is believed that efficiency gains would arise from shifting from a dry-matter basis to a nutrition centred allocation basis. This shift in focus would suggest a change in the 
management approach towards the likes of the TMR system. However, for such an approach to be operational in practice, precise knowledge on the nutritional demand of cows in the milking herd is required.

Climate, diet and animal factors are responsible for changes in the feed demand of a milking herd [8]. Within a milking herd, daily demand for nutrition, and in particular energy, of individual lactating cows depends on the level of milk produced, live weight, mobilisation of body tissue, and stage of gestation, all of which are characterised by typical lactation curve patterns that are a function of the day since a cow started producing milk [9]. Lactation curve models can be mechanistic or empirical. Mechanistic models are theoretical representations and underlying assumptions of the processes driving lactation while empirical models correspond to statistical representations of the reality being modelled [9]. When herd test data is available, fitting Legendre orthogonal polynomials using random regression is a flexible option to obtain a good characterisation of individual lactation curves and allow variation of curves among cows [9].

In addition to lactation curve modelling, the choice of the energy feeding system is important to define the energy requirements of individual cows. Different energy feeding systems are currently adopted in Europe [10,11] and North America [12], while the AFRC [11] is widely used to estimate energy requirements of grazing dairy cows in New Zealand. Yan et al. [13] assessed the performance of the AFRC [11], NRC [12] and INRA [11] feeding systems using data from long-term feeding studies and found no major differences in the estimation of energy requirements among systems except for the energy required for live weight change; where the NRC outperformed the INRA and AFRC systems. More recently, a review by Tedeschi et al. [14] has concluded that simpler feeding systems, such as the AFRC [11], are more resilient to variation in conditions among studies and robust enough to characterise milk production around the world.

Although several researchers [15-17] have determined the relationships between the ME content of diets and their influence on the performance of milking cows, these studies have been carried out under controlled conditions or involved few animals, making conclusions from such studies unscalable to the actual farm situation. Moreover, given the intrinsic dynamics of seasonal farming, it is unclear the extent to which requirements for ME of individual cows in a milking herd would vary given the variation of the energy content supplied daily in the diet. Knowing the extent to which requirements for ME of individual cows in a pasture-based dairy farm vary will contribute to the discussion of how such variation could potentially be used to improve efficiency in pasture-based dairy farm systems.

The objective of this study was to determine the extent to which the deviation of total metabolizable energy requirements of individual cows $\left(\mathrm{ME}_{\mathrm{t}}\right)$ from the ME supplied per cow in the herd (DME) varies throughout the production season in a pasture-based dairy farm using proximal hyperspectral sensing (PHS) of canopies.

\section{Materials and Methods}

\subsection{Study Farm}

This study was conducted at Dairy 1 farm at Massey University, Palmerston North, New Zealand (latitude $=-40^{\circ} 22^{\prime} 35.1^{\prime \prime}$, longitude $=175^{\circ} 36^{\prime} 51.1^{\prime \prime}$ ) during the 2016-2017 (from 29 July 2016 to 26 May 2017) and 2017-2018 (from 1 August 2017 to 29 May 2018) production seasons. The farm is characterised for being a low input pasture-based system with spring calving in which all cows are milked once daily throughout the production season. The main source of feed available on the farm throughout this study was grazed perennial ryegrass (Lolium perenne L.) and white clover (Trifolium repens L.) herbage mix. In addition to the use of herbage silage, mixed herb crops comprising chicory (Cichorium intybus), red clover (Trifolium pratense) and plantain (Plantago lanceolata), and monocultures of turnip (Brassica campestris ssp. rapifera), were grazed strategically to fill deficits in seasonal dry matter supply. In 2016-2017, lucerne (Medicago sativa) was grazed directly from paddocks while in 2017-2018, rape (Brassica napus), maize silage (Zea mays), tapioca 
(Manihot esculenta) and dried distillers grains pellets were introduced to the diet of cows. During the 2016-2017 and 2017-2018 production seasons, the dairy herd consisted of 260 and 255 cows, respectively, which were allocated an effective area of 119.7 ha. The herd breed composition was 25\% Holstein-Friesian (F), 14\% Holstein-Friesian crossbred (FX), $26 \%$ Holstein-Friesian-Jersey crossbred (FJ), 12\% Jersey crossbred (JX) and 22\% Jersey (J) based on the breed grouping criteria proposed by Handcock et al. [18].

\subsection{Data Collection}

Daily yields of milk (MY), fat (FY) and protein (PY) from cows in the herd were obtained from herd tests for fat and protein percentages and somatic cell counts performed monthly during the two production seasons. Live weights (LW) of individual cows identified with a radio frequency electronic identification system (Allflex New Zealand Ltd., Palmerston North, New Zealand) were automatically measured every morning after milking using a race walkover scale (WoW xR-3000, Tru-Test Ltd., Auckland, New Zealand). Calving dates, dry-off dates and dates of withholding periods for milk due to medicinal treatment were also documented. Volume of milk and kilograms of milk solids, fat and protein produced daily by the herd were monitored using the dairy company actual milk vat return records. Milk vat refers to the tank that is used to store raw milk produced at the farm until its collection by the dairy company the following day.

Herbage mass (HM) and metabolizable energy content (ME) of herbage from paddocks pre-grazing were measured every two to three weeks. At each measurement period, between four to six paddocks in the farm manager's weekly grazing plan were measured. Herbage mass was estimated using a C-Dax pasture meter with auto lift (Pasture Meter+ model 5008, C-Dax Agricultural Solutions, Turitea, NZ) towed behind an all-terrain vehicle following a " $\mathrm{W}$ " shaped pattern across the length of the paddock. C-Dax herbage height data collected within each paddock were averaged and converted to kilograms of dry matter (DM) per hectare with equation 1 developed and validated by Dairy 1 technical staff.

$$
\mathrm{HM}=752+16.3 \times \mathrm{H}
$$

where $\mathrm{H}$ is height $(\mathrm{mm})$.

Metabolizable energy was predicted from canopy reflectance measurements acquired with an ASD FieldSpec 4 High-Res proximal hyperspectral sensor (Analytical Spectral Devices Inc., Boulder, CO, USA) coupled with a canopy pasture probe system [19]. Metabolizable energy was determined using farm specific calibration models [20]. At each paddock, hyperspectral measurements were acquired from within twelve $50 \times 50 \mathrm{~cm}$ sampling plots distributed along the path of the C-Dax pasture meter. The number of plots was defined following recommendation of Cosgrove et al. [21] who suggested that twelve samples are required to determine the mean herbage ME of a paddock with an accuracy of $\pm 0.5 \mathrm{MJ} / \mathrm{kg}$ DM. At each grazing event, the area of herbage allocated to the cows was recorded. Post-grazing HM was measured using the same method as the one used to quantify HM at pre-grazing.

Daily allocation of supplementary feeds was obtained from farm records. The ME and gross energy (GE) content of the various feeds supplied to the cows was assumed (Table 1). 
Table 1. Metabolizable energy (ME) and gross energy (GE) of feeds other than fresh herbage offered to cows during the 2016-2017 and 2017-2018 production seasons at Dairy 1, Massey University, Palmerston North.

\begin{tabular}{cccc}
\hline Feed Source & ME (MJ/kg DM) & GE $^{\mathbf{1}} \mathbf{~ ( M J / k g ~ D M ) ~}$ & Reference \\
\hline Herbage silage & 9.5 & 19.0 & {$[22]$} \\
Herbage baleage & 10.2 & 19.0 & {$[22]$} \\
Chicory & 12.5 & 18.4 & {$[22]$} \\
Rape & 12.9 & 18.4 & {$[23]$} \\
Turnips & 12.0 & 18.4 & {$[22]$} \\
Lucerne & 11.0 & 18.4 & {$[22]$} \\
Maize silage & 10.3 & 19.0 & {$[22]$} \\
Tapioca & 12.8 & 18.8 & {$[22]$} \\
Dried distillers grains & 12.5 & 18.8 & {$[22]$} \\
\hline
\end{tabular}

${ }^{1}$ GE values were assumed following recommendations of AFRC [11].

\subsection{Data Editting}

In order to obtain a complete description of the feed offered daily at the farm during the two production seasons, days with missing data for HM, area of herbage offered to cows, post-grazing $\mathrm{HM}$, herbage ME were imputed using linear extrapolation.

The amount of herbage DM consumed by the herd at any paddock in any day was calculated as:

$$
\mathrm{HC}=\left(\mathrm{HM}_{\text {preg }}-\mathrm{HM}_{\text {postg }}\right) \times \mathrm{AH}
$$

where $\mathrm{HC}$ is the herbage consumed by the herd $(\mathrm{kg} \mathrm{DM}), \mathrm{HM}_{\text {preg }}$ is pre-grazing herbage mass ( $\mathrm{kg} \mathrm{DM} / \mathrm{ha}), \mathrm{HM}_{\text {postg }}$ is post-grazing herbage mass ( $\mathrm{kg} \mathrm{DM} / \mathrm{ha}$ ) and $\mathrm{AH}$ is the area of herbage allocated to cows (ha).

\subsection{Modelling of Cow Lactation Curves and Validation of Milk Production at Herd Level}

Orthogonal polynomials of third order were used to model lactation curves for MY, FY, PY and LW for each individual milking cow in each production season. Regression models for each trait were defined as a polynomial function of a cow's days in milk after calving as:

$$
\mathrm{Y}_{\mathrm{t}(\mathrm{c}: \mathrm{y})}=\left(\beta_{0} \times \mathrm{P}_{0}+\beta_{1} \times \mathrm{P}_{1}+\beta_{2} \times \mathrm{P}_{2}+\beta_{3} \times \mathrm{P}_{3}\right)+\left(\alpha_{0(\mathrm{c}: \mathrm{y})} \times \mathrm{P}_{0}+\alpha_{1(\mathrm{c}: \mathrm{y})} \times \mathrm{P}_{1}+\alpha_{2(\mathrm{c}: \mathrm{y})} \times \mathrm{P}_{2}+\alpha_{3(\mathrm{c}: \mathrm{y})} \times \mathrm{P}_{3}\right)+\mathrm{e}_{\mathrm{t}(\mathrm{c}: \mathrm{y})}
$$

where $Y_{t(c: y)}$ is the trait measured at day $t$ after calving of cow $\mathrm{c}$ within production season $y, \beta_{0}$ to $\beta_{3}$ are fixed regression coefficients representing the lactation curve of the population, $\alpha_{0(\mathrm{c}: \mathrm{y})}$ to $\alpha_{3(\mathrm{c}: \mathrm{y})}$ are random regression coefficients for cow c within production season $y, \mathrm{P}_{0}$ to $\mathrm{P}_{3}$ are Legendre polynomial functions of order 0 to 3 as defined below, and $e_{t(c: y)}$ is the random residual error. Coefficients of the orthogonal polynomial were calculated as:

$$
\mathrm{P}_{0}(\mathrm{t})=1 ; \mathrm{P}_{1}(\mathrm{t})=\mathrm{x} ; \mathrm{P}_{2}(\mathrm{t})=\frac{1}{2} \times\left(3 \times \mathrm{x}^{2}-1\right) ; \text { and } \mathrm{P}_{3}(\mathrm{t})=\frac{1}{2} \times\left(5 \mathrm{x}^{3}-3 \times \mathrm{x}\right)
$$

where $x$ is the number of days after calving standardised to a maximum lactation length of 270 days and calculated as:

$$
\mathrm{x}=-1+2 \times((\mathrm{t}-1) /(270-1))
$$

where $t$ is the number of days after calving.

Estimates of the fixed and random regression coefficients were obtained by solving the mixed model equations using the restricted maximum likelihood procedure as implemented in the R software package "lme4" (lme4, Version 2.74, R Package) [24].

The models developed here were used to predict MY, FY, PY and LW for each cow in the herd for every calendar day of the 2016-2018 and 2017-2018 production seasons. 
At any given day, a cow was assumed to be in the milking herd if the day was one week after their calving date or before their drying-off date and there were no records of the cow being withheld from milking. Modelled yields of milk, fat and protein of individual cows were added by calendar day and daily totals were validated against actual milk production obtained in the milk vat. Modelled lactation curves were then used to estimate requirements for ME of each of the cows in the milking herd at every calendar day along production seasons as described in Section 2.5.

\subsection{Metabolizable Energy Requirements of Cows and Energy Balance at Herd Level}

The ME content in the diet supplied daily to the herd was calculated as the weighted average of the ME content of the feed source in relation to the quantity of feed supplied in dry matter (DM). Likewise, metabolicity of the diet (qm), calculated as the quotient $\mathrm{ME} / \mathrm{GE}$, was also based on the weighted average of the energy contents of feeds, where the value for GE of fresh herbage was assumed at $18.4 \mathrm{MJ} / \mathrm{kg}$ DM and values for ME and GE of the remaining feeds were also assumed and presented in Table 1.

Efficiency of ME use for the various animal functions were calculated or assumed constant following AFRC [11] Equations (6) to (11):

$$
\begin{gathered}
\text { Efficiency for maintenance }\left(\mathrm{k}_{\mathrm{m}}\right)=0.35 \times \mathrm{qm}+0.503 \\
\text { Efficiency for lactation }\left(\mathrm{k}_{\mathrm{l}}\right)=0.35 \times \mathrm{qm}+0.420 \\
\text { Efficiency for live weight gain }\left(\mathrm{k}_{\mathrm{g}}\right)=0.95 \times \mathrm{k}_{1} \\
\text { Efficiency for live weight loss }\left(\mathrm{k}_{\mathrm{t}}\right)=0.84 \\
\text { Efficiency for growth of conceptus }\left(\mathrm{k}_{\mathrm{c}}\right)=0.133
\end{gathered}
$$

The ME requirement for maintaining ( $\mathrm{ME}_{\mathrm{m}}$; in $\mathrm{MJ} /$ day) a cow at any given calendar day was calculated as the addition of the energetic requirements for their fasting metabolism (Fm) and an activity allowance (Ac) that assumed a constant walking distance of $3 \mathrm{~km}$ as:

$$
\begin{gathered}
\mathrm{ME}_{\mathrm{m}}=(\mathrm{Fm}+\mathrm{Ac}) / \mathrm{k}_{\mathrm{m}} \\
\mathrm{Fm}=\left(0.53 \times\left(\mathrm{LW}_{\mathrm{d}} / 1.08\right)^{0.67}\right) \\
\mathrm{Ac}(\mathrm{MJ} / \text { day })=0.0016 \times \mathrm{LW}_{\mathrm{d}}
\end{gathered}
$$

where $\mathrm{LW}_{\mathrm{d}}$ is the modelled live weight of a cow at calendar day $\mathrm{d}$.

Cow $\mathrm{ME}$ requirement for lactation $\left(\mathrm{ME}_{1}\right.$; in $\mathrm{MJ} /$ day) was calculated as:

$$
\mathrm{ME}_{1}=\left(\mathrm{EV}_{1} \times \mathrm{MY} \times 1.03\right) / \mathrm{k}_{1}
$$

where $\mathrm{EV}_{1}$ is the energy value of a kilogram of milk calculated as:

$$
\mathrm{EV}_{1}(\mathrm{MJ} / \mathrm{kg})=0.376 \times \mathrm{F}+0.209 \times \mathrm{P}+0.948
$$

where $\mathrm{F}$ and $\mathrm{P}$ are percentages of fat and protein in milk, respectively.

Metabolizable energy requirement for live weight change $\left(\mathrm{ME}_{\mathrm{g}}\right.$; in $\mathrm{MJ} /$ day) was calculated with Equation (16) if the cow was gaining weight or with Equation (17) if the cow was losing weight.

$$
\begin{gathered}
\mathrm{ME}_{\mathrm{g}}=\left(\mathrm{EV}_{\mathrm{g}} \times \mathrm{LWC}\right) / \mathrm{k}_{\mathrm{g}} \\
\mathrm{ME}_{\mathrm{g}}=\mathrm{EV}_{\mathrm{g}} \times \mathrm{LWC} \times \mathrm{k}_{\mathrm{t}} / \mathrm{k}_{\mathrm{l}}
\end{gathered}
$$

where $\mathrm{EV}_{\mathrm{g}}$ is the energy value of a kilogram of live body tissue assumed constant at $19 \mathrm{MJ} / \mathrm{kg}$ [11] and LWC is the daily live weight change of a cow as determined by the first derivative of modelled daily live weights. 
Metabolizable energy requirement to sustain the growth of the conceptus $\left(\mathrm{ME}_{\mathrm{c}}\right.$; in $\mathrm{MJ} /$ day) was calculated as:

$$
\mathrm{EV}_{\mathrm{c}} / \mathrm{k}_{\mathrm{c}}
$$

where $\mathrm{EV}_{\mathrm{c}}$ is the energy retained by the fetus at any given day after conception and calculated as:

$$
\mathrm{EV}_{\mathrm{c}}=1 / 40 \times \mathrm{W}_{\mathrm{c}} \times\left(\mathrm{E}_{\mathrm{t}} \times 0.0201 \times \mathrm{e}^{-0.0000576 \times \mathrm{t}}\right)
$$

where $E_{t}$ is the total energy retained by the fetus in MJ at day $t$ after conception derived from:

$$
\log 10\left(E_{t}\right)=151.665-151.64 \mathrm{e}^{-0.0000576 \times t}
$$

and $\mathrm{W}_{\mathrm{c}}$ is the calf weight at birth in kg calculated as:

$$
\mathrm{W}_{\mathrm{c}}=\left(\mathrm{LW}_{\mathrm{m}}^{0.73}-28.89\right) / 2.064
$$

where $L W_{m}$ is the cow's averaged live weight between days 100 and 200 after calving. Conception date of each cow was calculated by subtracting 283 days to the date of calving at the subsequent production season. It was assumed that cows not present in the herd in the subsequent production season were empty with an $\mathrm{EV}_{\mathrm{c}}$ equal to zero.

The total cow requirements for $\mathrm{ME}\left(\mathrm{ME}_{\mathrm{t}}\right.$; in $\mathrm{MJ} /$ day) were adjusted for feeding level as:

$$
\mathrm{ME}_{\mathrm{t}}=[1+0.018 \times(\mathrm{FL}-1)] \times\left(\mathrm{ME}_{\mathrm{m}}+\mathrm{ME}_{1}+\mathrm{ME}_{\mathrm{g}}+\mathrm{ME}_{\mathrm{c}}\right)
$$

where FL is the feeding level calculated by dividing the sum of $M E_{m}, M E_{1}, M E_{g}$ and $M E_{c}$ over $\mathrm{ME}_{\mathrm{m}}$.

Estimated requirements for $\mathrm{ME}_{t}$ of individual cows were added by calendar day to determine the daily $\mathrm{ME}_{\mathrm{t}}$ estimated requirements of the herd. Then, herd $\mathrm{ME}_{\mathrm{t}}$ requirements were contrasted with daily ME supplied at the farm. The herd was considered sub or over fed if their $\mathrm{ME}_{\mathrm{t}}$ estimated requirements was above or below $5 \mathrm{MJ} / \mathrm{kg}$ DM of the mean ME value of the diet supplied daily. The $\pm 5 \mathrm{MJ} / \mathrm{kg}$ DM tolerance was based on the error associated with the herbage ME sampling method.

Descriptive statistics were used to visualise variation of estimated requirements for $\mathrm{ME}_{\mathrm{t}}$ of individual cows along with the actual ME supplied per cow in the herd $\left(\mathrm{ME}_{\mathrm{s}}\right.$; $\mathrm{MJ} /$ cow / day). Variation of daily $\mathrm{ME}_{\mathrm{t}}$ estimated requirements of cows within calendar days was represented by boxplots, while averaged daily $\mathrm{ME}_{\mathrm{t}}$ estimated requirements grouped by breed were used to represent daily energy required by each of the five breeds in the herd.

The difference between a cow's daily $\mathrm{ME}_{\mathrm{t}}$ estimated requirements and $\mathrm{ME}_{\mathrm{s}}$ was defined and calculated as the deviation of the daily $\mathrm{ME}_{\mathrm{t}}$ estimated requirements of a cow from the actual ME supplied per cow in the herd (DME; in MJ/day).

\subsection{Statistical Analysis}

A repeated measures analysis of variance for DME was performed using the "lme4" package for R software (lme4, Version 2.74, R Package) to obtain estimates of the variance reflected by the levels of the factors in the following linear model:

$$
\mathrm{DME}_{\mathrm{ij}}=\mu+\mathrm{C}_{\mathrm{i}}+\mathrm{B}_{\mathrm{j}}+\mathrm{e}_{\mathrm{ij}}
$$

where $\mathrm{DME}_{\mathrm{ij}}$ is the deviation of the daily $\mathrm{ME}_{t}$ estimated requirements of cow $i$ of breed $j$ from the ME supplied per cow in the herd, $\mu$ is the mean value of DME, $C_{i}$ is the random effect of the $i$-th cow in the herd (318 different identification classes), $B_{j}$ is the random effect of the $\mathrm{j}$-th breed (either F, FX, FJ, JX or J) and $e_{i j}$ is the random residual error associated with each observation.

Estimates of variance components for cow $\left(\sigma^{2}{ }_{c}\right)$, breed $\left(\sigma^{2} b\right)$ and residual error $\left(\sigma^{2} \mathrm{e}\right)$ were used to calculate total variance $\left(\sigma^{2} \mathrm{~T}\right)$ as $\sigma^{2} \mathrm{~T}=\sigma^{2}{ }_{\mathrm{C}}+\sigma^{2}{ }_{\mathrm{b}}+\sigma^{2}$. The contribution of breed, cow and residual error were also expressed as the percentage of the total variance. 


\section{Results}

\subsection{Descriptive Statistics}

Descriptive statistics on cow variables collected via herd tests, cow live weights, daily yields of milk, fat and protein per cow calculated from milk vat records as well as data collected on grazed herbage and feeds supplied to the herd during the 2016-2017 and 2017-2018 production seasons are presented in Table 2.

Table 2. Descriptive statistics of yields of milk, fat, protein and live weights of individual cows, milk vat records, grazed herbage measurements and supplementary feed allowances for the 2016-2017 and 2017-2018 production seasons at Dairy 1, Massey University, Palmerston North.

\begin{tabular}{|c|c|c|c|c|c|c|c|c|c|}
\hline \multirow{2}{*}{ Data Source } & \multirow{2}{*}{ Variable } & \multicolumn{4}{|c|}{ 2016-2017 } & \multicolumn{4}{|c|}{ 2017-2018 } \\
\hline & & $\mathbf{N}$ & Mean & SD & $\mathrm{CV} \%$ & $\mathbf{N}$ & Mean & SD & $\mathrm{CV} \%$ \\
\hline \multirow{4}{*}{ Individual cows } & MY & 2296 & 15.6 & 6.05 & 38.8 & 1933 & 16.3 & 6.4 & 39.3 \\
\hline & FY & 2296 & 0.81 & 0.26 & 32.1 & 1932 & 0.84 & 0.3 & 35.7 \\
\hline & PY & 2296 & 0.63 & 0.19 & 30.2 & 1933 & 0.65 & 0.21 & 32.3 \\
\hline & LW & 34646 & 493.9 & 69.5 & 14.1 & 33064 & 491.9 & 65.2 & 13.3 \\
\hline \multirow{3}{*}{ Milk vat ${ }^{1}$} & Milk & 300 & $\begin{array}{c}3231 \\
(14.4)\end{array}$ & $\begin{array}{l}1047 \\
(3.2)\end{array}$ & $\begin{array}{c}- \\
(22.3)\end{array}$ & 302 & $\begin{array}{c}3136 \\
(14.7)\end{array}$ & $\begin{array}{l}1097 \\
(3.42)\end{array}$ & $\begin{array}{c}- \\
(23.2)\end{array}$ \\
\hline & Fat & 300 & $\begin{array}{c}174 \\
(0.78)\end{array}$ & $\begin{array}{c}50 \\
(0.13)\end{array}$ & $\begin{array}{c}- \\
(16.7)\end{array}$ & 302 & $\begin{array}{c}164 \\
(0.77)\end{array}$ & $\begin{array}{c}52 \\
(0.15)\end{array}$ & $\begin{array}{c}- \\
(19.5)\end{array}$ \\
\hline & Protein & 300 & $\begin{array}{c}132 \\
(0.59)\end{array}$ & $\begin{array}{c}36 \\
(0.10)\end{array}$ & $\begin{array}{c}- \\
(16.9)\end{array}$ & 302 & $\begin{array}{c}126 \\
(0.60)\end{array}$ & $\begin{array}{c}37 \\
(0.10)\end{array}$ & $\begin{array}{c}- \\
(16.7)\end{array}$ \\
\hline \multirow{4}{*}{ Grazed herbage } & $\mathrm{HM}_{\text {preg }}$ & 66 & 2960.7 & 208.6 & 7.0 & 111 & 2920.1 & 211.2 & 7.2 \\
\hline & $\mathrm{HM}_{\text {postg }}$ & 66 & 1798.8 & 147.8 & 8.2 & 111 & 1702.5 & 119.7 & 7.0 \\
\hline & ME & 66 & 11.2 & 0.31 & 2.8 & 111 & 10.7 & 0.53 & 5.0 \\
\hline & GA & 66 & 2.4 & 0.83 & 34.6 & 111 & 1.92 & 0.81 & 42.2 \\
\hline \multirow{9}{*}{$\begin{array}{l}\text { Supplementary } \\
\text { feed allowances } \\
\text { (kg DM/cow/day) }\end{array}$} & Herbage silage & 66 & 1.13 & 1.63 & - & 111 & 1.31 & 2.41 & - \\
\hline & Herbage bailage & 66 & 0 & 0 & - & 111 & 0.12 & 0.33 & - \\
\hline & Chicory & 66 & 1.26 & 1.74 & - & 111 & 1.56 & 2.07 & - \\
\hline & Rape & 66 & 0 & 0 & - & 111 & 0.25 & 0.97 & - \\
\hline & Turnips & 66 & 0.15 & 0.87 & - & 111 & 0.54 & 1.37 & - \\
\hline & Lucerne & 66 & 0.55 & 1.32 & - & 111 & 0 & 0 & - \\
\hline & Maize silage & 66 & 0 & 0 & - & 111 & 0.1 & 0.56 & - \\
\hline & Tapioca & 66 & 0 & 0 & - & 111 & 0.32 & 0.66 & - \\
\hline & DDG & 66 & 0 & 0 & - & 111 & 0.53 & 1.04 & - \\
\hline
\end{tabular}

${ }^{1}$ Descriptive statistics of milk in the vat calculated per cow considering only the cows present in the milking herd at the day records were obtained are presented between brackets. $\mathrm{MY}=$ milk yield $(\mathrm{L} /$ day), $\mathrm{FY}=$ fat yield $(\mathrm{kg} \mathrm{F} /$ day), $\mathrm{PY}=$ protein yield $(\mathrm{kg} \mathrm{P} / \mathrm{day}), \mathrm{LW}=\mathrm{live}$ weight (kg LW/day), Milk = milk volume in vat (L/day), Fat = milk fat in vat ( $\mathrm{kg} \mathrm{F} /$ day) or ( $\mathrm{kg} \mathrm{F} /$ cow day), Protein = milk protein in vat $(\mathrm{kg} \mathrm{P} /$ day $)$ or $(\mathrm{kg} \mathrm{P} /$ cow $/$ day $), \mathrm{HM}_{\text {preg }}=$ pre-grazing herbage mass $(\mathrm{kg} \mathrm{DM} / \mathrm{ha}), \mathrm{HM}_{\text {postg }}=$ post-grazing herbage mass $(\mathrm{kg} \mathrm{DM} / \mathrm{ha}), \mathrm{ME}=$ metabolizable energy $(\mathrm{MJ} / \mathrm{kg} \mathrm{DM}), \mathrm{GA}=$ allocated herbage grazing area (ha/day), $\mathrm{DDG}=$ dried distillers grains, $\mathrm{F}=$ fat, $\mathrm{P}=\mathrm{protein}, \mathrm{DM}=$ dry matter, $\mathrm{N}=$ number of samples, $\mathrm{SD}=$ standard deviation, $\mathrm{CV} \%=$ coefficient of variation in percentage.

\subsection{Metabolizable Energy Composition of the Diet of the Herd}

Composition of the ME of the diet consumed daily by the cows in the milking herd varied throughout the production seasons (Figure 1).

Grazed herbage supplied an average of $73 \%$ of the ME consumed daily by the herd in the farm. However, the supply of ME from herbage in relation to the many feeds offered varied within and between production seasons. Early in the seasons, the ME in the diet was composed of about $80 \%$ herbage and $20 \%$ herbage silage, reaching to $100 \%$ herbage on most spring days. As production seasons unfolded, crops such as chicory, turnips and rape became available and supplied cows with a source of ME during summer and into the autumn. However, the use of these crops occurred earlier in 2017-2018 than in 2016-2017. From February onwards in 2017-18, lucerne and herbage silage were replaced with herbage baleage, maize silage, tapioca and DDG and there was a decrease in the use of herb crops as sources of ME compared to the 2016-2017 production season. 


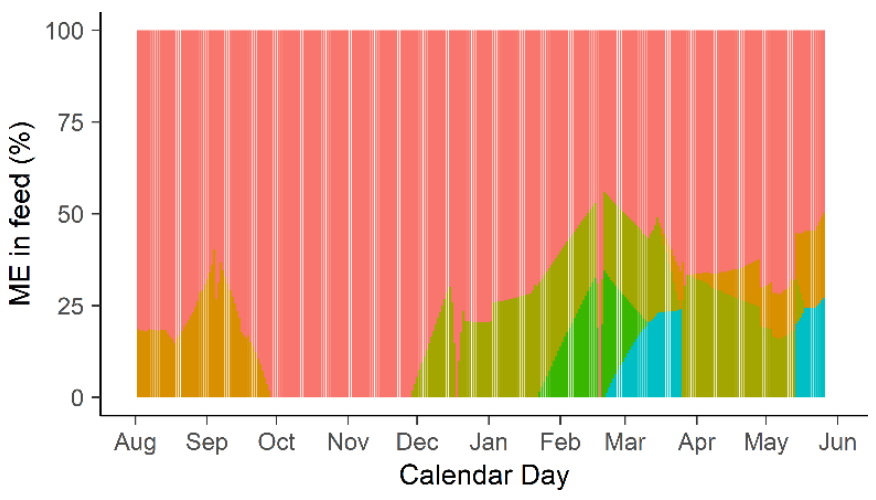

(a)

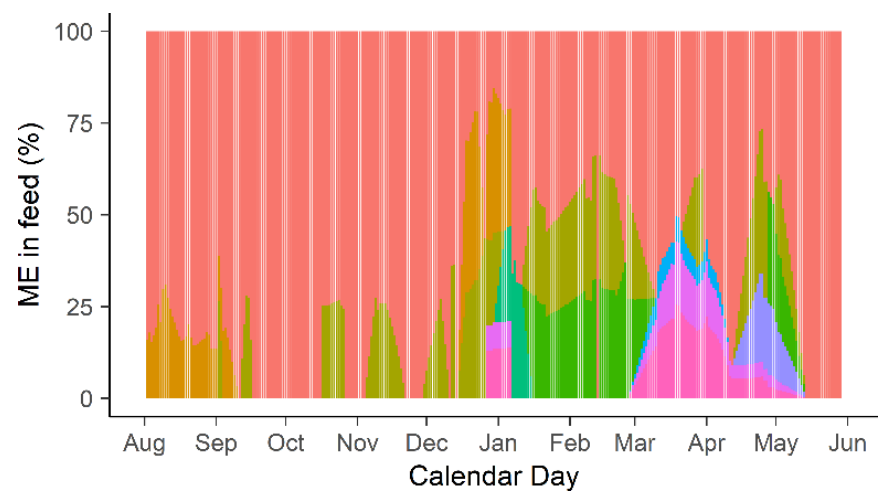

(b)
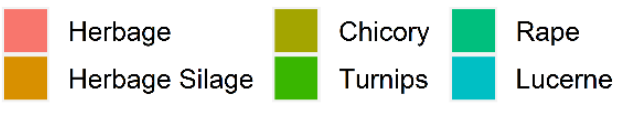

Herbage Baleage
Maize Silage

Tapioca

Dried Distillers Grains

Figure 1. Metabolizable energy (ME) composition of feed allocated daily to the milking herd during the 2016-2017 (a) and 2017-2018 (b) production seasons at Dairy 1, Massey University, Palmerston North.

\subsection{Metabolizable Energy Balance at Herd Level}

Modelling of individual cow milk traits upscaled to the herd level was able to explain variability of milk obtained at the milk vat with high $\mathrm{R}^{2}$ and low relative prediction error (RPE) values $\left(R^{2}>0.95\right.$ and $R P E<9 \%$ ) (Figure 2 ).

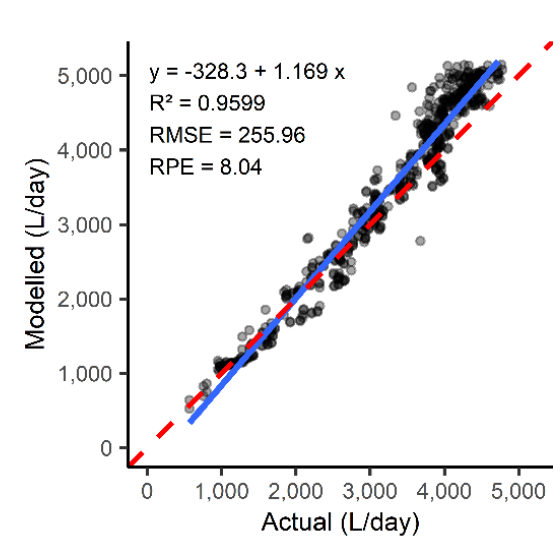

(a)

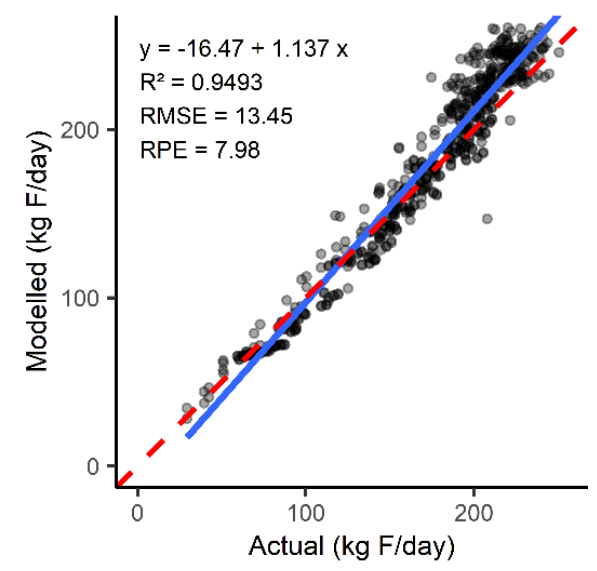

(b)

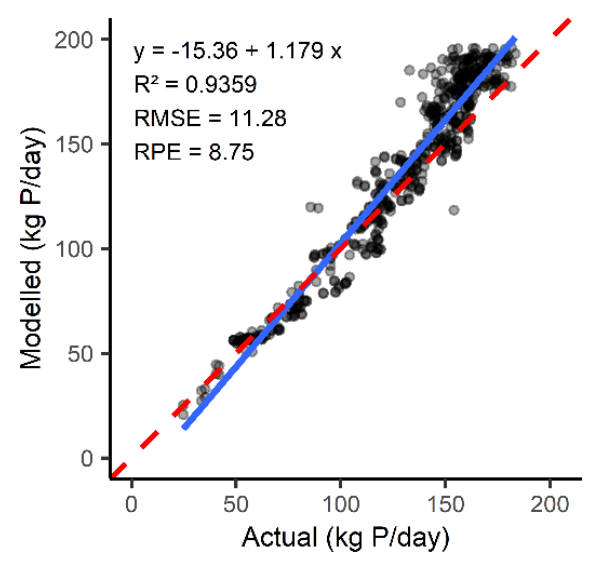

(c)

Figure 2. Validation of modelled milk (a), fat (b) and protein (c) produced daily by the milking herd against actual milk production measured in vat at Dairy 1, Massey University, Palmerston North. (-) linear regression line, (- - -) reference line with intercept of 0 and slope of $1 . y=$ dependent variable of the linear regression equation denoting modelled daily milk production, $x=$ independent variable of the linear regression equation denoting actual daily milk production measured in the milk vat, $\mathrm{R}^{2}=$ coefficient of determination, $\mathrm{RMSE}=$ root mean squared error, $\mathrm{RPE}=$ relative prediction error.

There were significant relationships $(p<0.001)$ between the amount of ME supplied daily by management to the milking herd and the daily ME estimated requirements of the herd on both production seasons, with both production seasons exhibiting similar $\mathrm{R}^{2}$, RMSE and RPE values (Figure 3). 


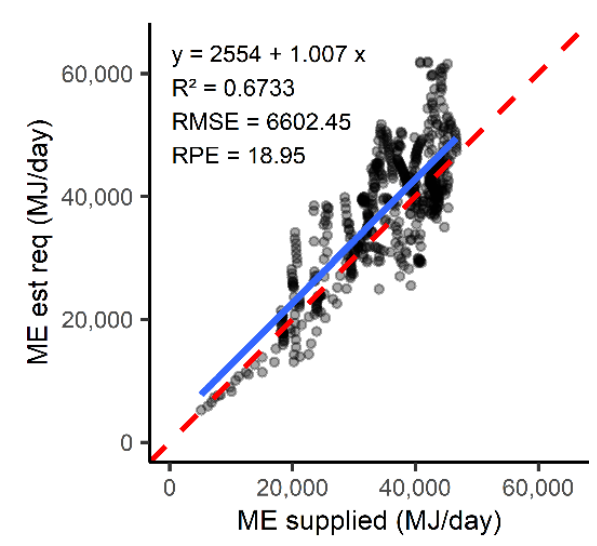

(a)

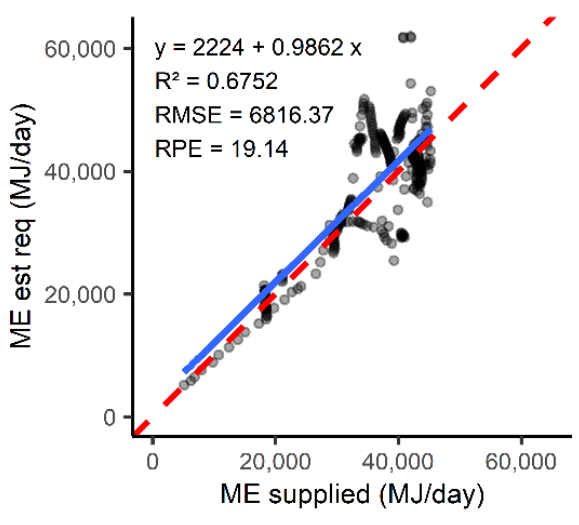

(b)

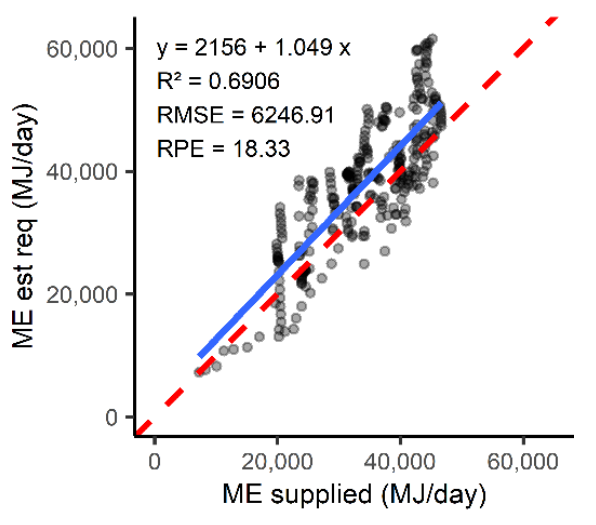

(c)

Figure 3. Relationship between daily metabolizable energy supplied (ME supplied) and daily metabolizable energy estimated requirements (ME est req) of the milking herd at Dairy 1, Massey University, during the 2016-2017 and 2017-2018 (a), 2016-2017 (b) and 2017-2018 (c) production seasons. (-) linear regression line, (- - -) reference line with intercept of 0 and slope of 1. $\mathrm{y}=$ dependent variable of the linear regression equation denoting estimated requirements for ME of the milking herd, $x=$ independent variable of the linear regression equation denoting actual ME supplied to the milking herd, $\mathrm{R}^{2}=$ coefficient of determination, $\mathrm{RMSE}=$ root mean squared error, $\mathrm{RPE}=$ relative prediction error.

The amount of ME supplied daily to the herd throughout production seasons matched the estimated requirements of the herd on $25 \%$ of the days. Conversely, ME was undersupplied in up to $30 \mathrm{MJ} / \mathrm{cow} /$ day on $64 \%$ of the days and over-supplied in $4.3 \mathrm{MJ} / \mathrm{cow} /$ day on $11 \%$ of the days. The depiction of daily supply and demand for ME shows that most of the days in which intake of $\mathrm{ME}$ was below the herds' $\mathrm{ME}_{\mathrm{t}}$ estimated requirements were at the start of the production seasons (Figure 4). However, there were also various days during summer in which the energy balance was also negative (daily ME supplied below $\mathrm{ME}_{\mathrm{t}}$ estimated requirements).

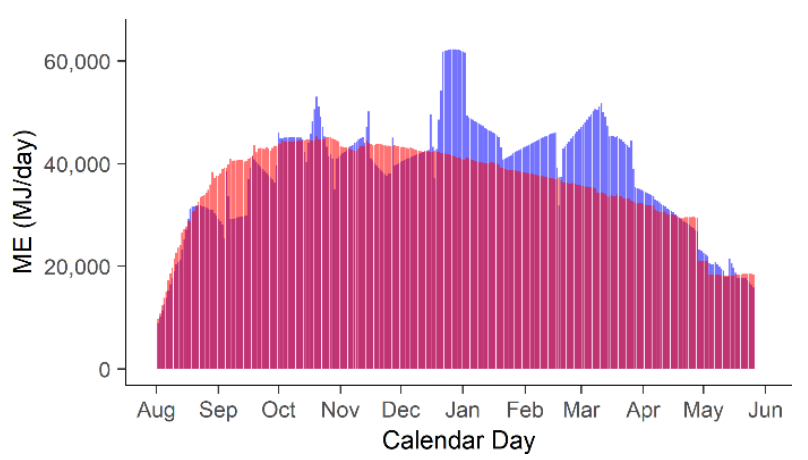

(a)

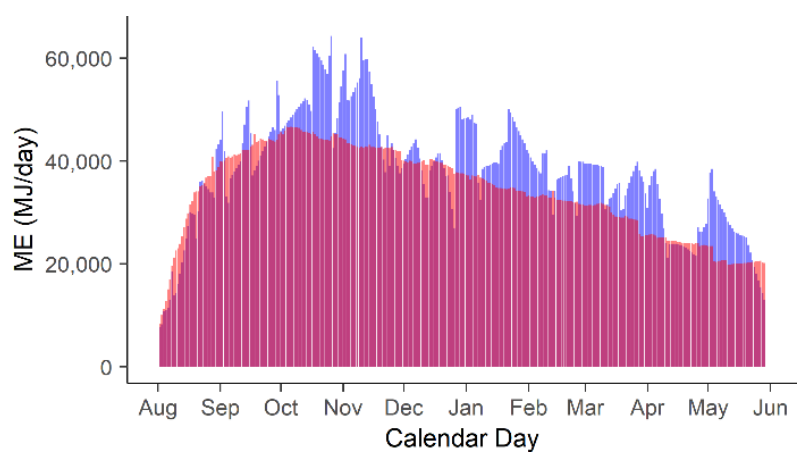

(b)

ME supplied

ME estimated requirements

Figure 4. Daily metabolizable energy (ME) supplied to the milking herd and ME estimated requirements of the milking herd at Dairy 1, Massey University, during the 2016-2017 (a) and 2017-2018 (b) production seasons.

\subsection{Variation of DME}

The mean DME calculated throughout productions seasons was $14.4 \mathrm{MJ} / \mathrm{cow} /$ day and the standard deviation was 39.0 MJ/cow/day. The variation of DME throughout the 20162017 and 2017-2018 production seasons at Dairy 1 farm can be visualized as the difference between individual cow or breed $\mathrm{ME}_{\mathrm{t}}$ estimated requirements and the ME supplied to the herd presented in Figure 5. Boxplots indicate that variation of the estimated requirements 
for $\mathrm{ME}_{\mathrm{t}}$ of individual cows throughout production seasons was high $(\mathrm{CV}=18.8 \%)$, with such variation being greater at earlier than at mid to later stages of the production seasons (Figure 5). Holstein-Friesian was the breed whose estimated requirements for $\mathrm{ME}_{\mathrm{t}}$ varied the most $(\mathrm{CV}=18.7 \%)$ while Jersey the least $(\mathrm{CV}=16.9 \%)$. The average level of $\mathrm{ME}$ supplied per cow in the herd was at most days below the level required by F or FX cows but higher than that $\mathrm{ME}_{t}$ estimated requirements of J cows (Figure 5). Differences of DME between cows were nearly four times greater than differences between breeds.

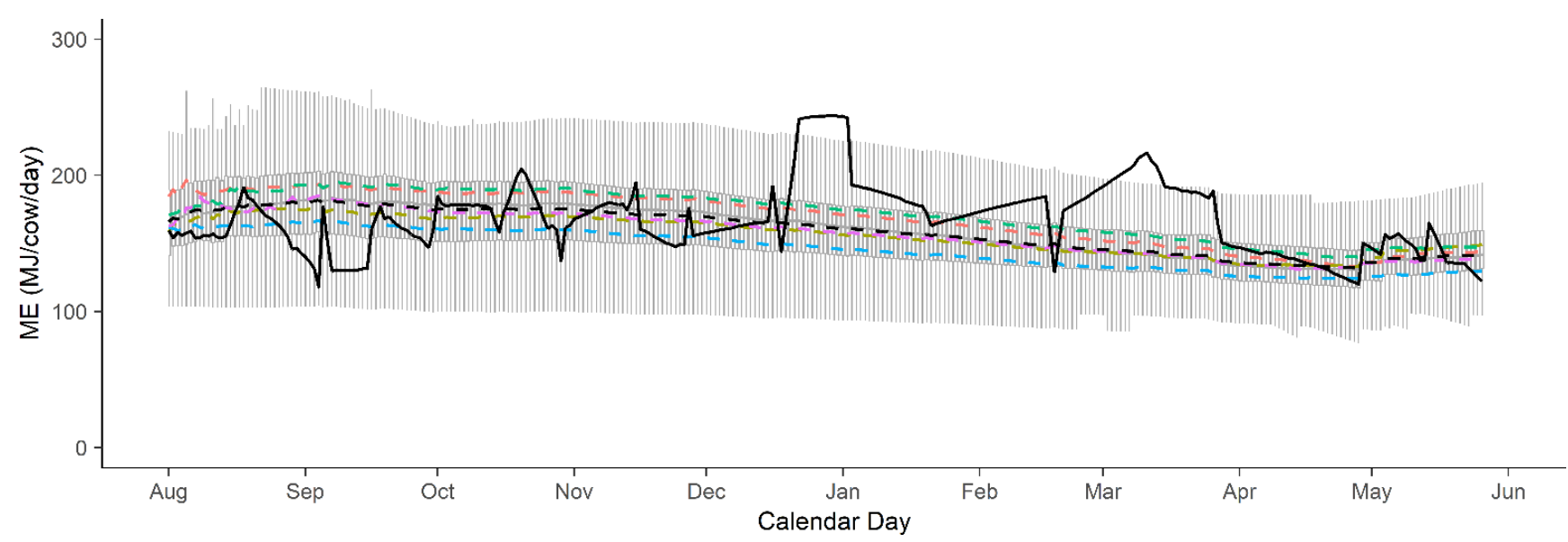

(a)

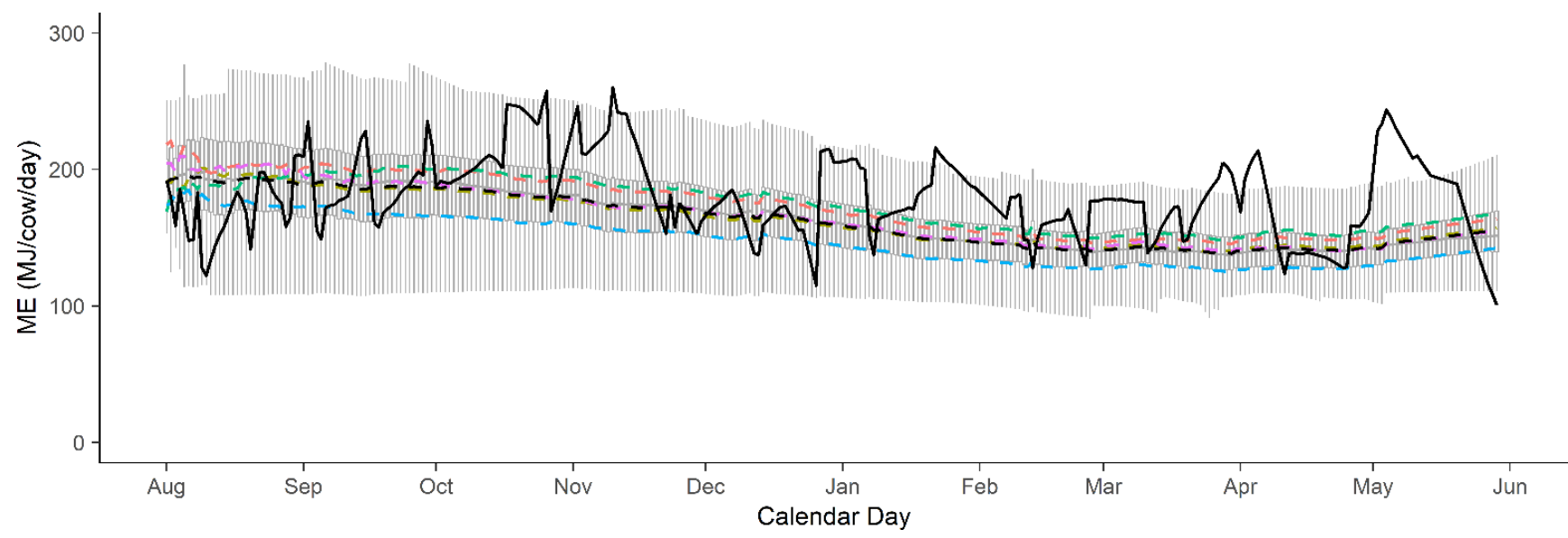

(b)

ME estimated requirements

ME supplied

- - F - FX - - FJ - J JX - J - - Herd

- Herd

Figure 5. Daily variation of dietary metabolizable energy (ME) supplied per cow in the herd, mean ME estimated requirements per cow in the herd, mean ME estimated requirements per cow grouped by breed, and dispersion of ME estimated requirements of individual cows (boxplots) during the 2016-2017 (a) and 2017-2018 (b) production.

Results of the analysis of variance performed on DME in show that the relative contribution of breed and cow to total variance was relatively low compared to the error associated with observations within cows indicated by the random error term $\left(e^{2}\right)$ (Table 3$)$. 
Table 3. Variance decomposition of the deviation of the daily total metabolizable energy estimated requirements of a cow from the actual metabolizable energy supplied per cow in the herd (DME) at Dairy 1, Massey University, during the 2016-2017 and 2017-2018 production seasons.

\begin{tabular}{cccccccc}
\hline & $\boldsymbol{\sigma}^{2}{ }_{\mathbf{c}}$ & $\boldsymbol{\sigma}^{2}{ }_{\mathbf{b}}$ & $\boldsymbol{\sigma}^{2}{ }_{\mathbf{e}}$ & $\boldsymbol{\sigma}^{2}{ }_{\mathbf{T}}$ & $\mathbf{c}^{2}$ & $\mathbf{b}^{\mathbf{2}}$ & $\mathbf{e}^{2}$ \\
\hline DME & 471.5 & 120.2 & 1027.0 & 1618.7 & 29.1 & 7.4 & 63.4 \\
\hline
\end{tabular}

$\sigma^{2}{ }_{c}=$ variance explained by the random effect of cow, $\sigma_{b}^{2}=$ variance explained by the random effect of breed $\sigma^{2}{ }_{e}=$ variance explained by the random error, $\sigma^{2} \mathrm{~T}=$ total variance, $\mathrm{c}^{2}=$ variance explained by the random effect of cow expressed as a percentage of total variance, $b^{2}=$ variance explained by the random effect of breed expressed as a percentage of total variance, $\mathrm{e}^{2}=$ variance explained by random error expressed as a percentage of total variance.

\section{Discussion}

Mean values of daily yields per cow of milk, fat and protein obtained from herd tests were slightly higher than yields calculated from milk vat records. Moreover, mean yields reported here were about $46 \%, 50 \%$ and $51 \%$ higher than the yields of milk, fat and protein, respectively reported in other comparable studies involving once a day milking but higher stocking rates ( $>3$ cows/ha) [25-27]. Despite the differences in yields, mean live weights used here were within the ranges of live weights reported in the studies mentioned before (from 375 to $511 \mathrm{~kg}$ ). Mean and standard deviation values of herbage ME predicted from canopy reflectance were within the normal values commonly found in the literature $[1,22,28]$. Likewise, herbage mass measures at pre-grazing were within normal ranges observed for ryegrass dominant herbage swards (from 2200 to $3700 \mathrm{~kg}$ $\mathrm{DM} / \mathrm{ha}$ ) [1,29] while herbage mass measures obtained at post-grazing were slightly higher than the most frequent measures observed by McCarthy et al. [30], which ranged from 1480 to $1760 \mathrm{~kg}$ DM/ha. Higher than normal post-grazing residuals might help explain the higher yields measured in this study compared to those reported in other comparable studies [25-27].

Modelling of lactation curves of individual cows for the two production seasons was able to capture the production of milk in the vat. However, the negative offsets and slopes greater than one in the linear regression equations (Figure 2) indicate that modelling tended to overestimate production as measured in the milk vat at days with high levels of production and to underestimate production at lower levels of milk production, but that although significant $(p<0.001)$, the magnitude of these effects was minimal. It is important to highlight however that milk vat records might not be an accurate representation of the actual milk produced daily at the farm, since milk produced at the farm was used to rear calves and was not available and therefore not included in the milk vat records, also the milk from any cow on medication was not included in the vat. Because demand for milk by calves is high when milk production levels are high, the differences between herd tests and milk vat records can explain the differences between yields measured at herd tests and yields calculated from milk present in the vat (Table 2), and therefore, the slight overestimation by the modelling approach. The underestimation of milk produced at lower levels of production by modelling might be the consequence of underestimating the number of cows being milked at the beginning of the production seasons when production is low, as this number was set by a fixed milk withholding period of seven days, which might have been lower than the actual number of cows milked at that stage. Moreover, the use of orthogonal polynomial functions, which were found to introduce errors at both ends of modelled lactation curves [31,32] can also help explain the differences between modelled and actual milk produced at the vat, particularly at both ends of the production seasons.

Accuracy and bias metrics describing the relationship between the daily ME supplied and estimated requirements of the herd (Figure 3) indicated that there were opportunities in the farm to further improve the balance between supply and demand of energy. An RPE value of $18.9 \%$ means that the daily ME estimated requirements of the herd were, on average, nearly a fifth above or below the daily mean ME supplied. Moreover, there was a slight systematic tendency to under supply ME as denoted by the slope greater than one in the equation regression (Figure 3). The profile of the ME supplied against herd 
daily estimated requirements shows that most of the undersupplied days were at early stages in the production seasons. This is consistent with theoretical representations of dry matter supply and demand in seasonal pasture-based dairy farm systems [1]. The relative undersupply of dietary ME at early stages in the production seasons is well known and is explained by cows entering a stage of negative energy balance postpartum that is characterised by physical constrain of intake and weight loss to support metabolic functioning [33]. Although feeding strategies can be developed to overcome the effects of the negative energy balance at early lactation, allowing for the physiological capability of cows to rapidly mobilise energy from fat tissue instead of incorporating sources of energy in the diet is perhaps the most profitable strategy for managing feed at this stage. Oversupply of energy during most days from October onwards signifies that supplements could have been saved if allocation of feeds were made based on rapid measurements of herbage ME. However, this would have not only required rapid ME measurement tools but also precise forecasting tools that were able to accurately assist with tactical planning and budgeting for the season.

Greater dispersion of individual cow daily $\mathrm{ME}_{\mathrm{t}}$ estimated requirements at early stages of the production seasons can be explained by greater variation of peak yields than in persistency of lactations of individual cows in the herd. This can be supported by the high levels of ME supplied per cow that occurred after January in both production seasons (Figure 5) that are most likely to have contributed to sustain persistency of lactation after peak yields. If daily variation of estimated requirements for $\mathrm{ME}_{\mathrm{t}}$ is grouped by breed and compared against the mean dietary ME supplied per cow in the herd, then results show that the energy required by F cows was below the mean energy supplied per cow on $49 \%$ of the days studied, while this metric was only $17 \%$ for J cows. F cows must have a different grazing behaviour (i.e., bite rate, bite mass and/or grazing time) compared to J cows in order to achieve greater intakes to satisfy their energy demands.

The contribution of within cow variation on explaining variance of DME can be partially explained by the fact that daily estimated requirements for $\mathrm{ME}_{t}$ of individual cows throughout lactations varied more than the variation of the supply of ME per cow at the herd level throughout the production seasons. Because of this, the differences of DME within individual cows were greater than the differences of DME between cows or breeds. This finding stresses on the importance of performing regular monitoring of a cow's $\mathrm{ME}_{\mathrm{t}}$ requirements to inform daily allocation of ME to cows to minimize DME. Most pasture-based dairy herds are managed as a single mob, where all cows have access to the same feed resources and thus a precise fit between ME demand and supply of each individual cow is unlikely to be easily implemented. However, having accurate estimates of the $\mathrm{ME}_{\mathrm{t}}$ requirements of individual cows and the $\mathrm{ME}$ content of the diet on any given day can potentially help management to achieve a more precise balance between demand and supply of energy though improved decision-making without having to bring significant changes to the production system or management.

Measurement error can potentially affect decision making around DME management. In this study, the estimation of daily ME demand was based on modelling of lactation curves which is likely to be subject to error if compared to actual daily measurements. Moreover, there is a level of error associated with herbage ME measurement due to accuracy of the PHS tool [20] and the sampling strategy chosen [21]. Moreover, estimation of DME variation is also likely to be subject to measurement error of MY, FY, PY and LW of individual cows as this error is embedded in the within cow factor used in random regression. In addition to measurement error, another source of error in the estimation of the ME supplied by the diet is associated with the use of assumed, instead of actual, ME values for supplementary feeds assessment. Measurement and assumptions induced errors limit the scope of this study to DME management, but to our understanding, no study has been published to date with the level of detail of the data presented here.

Several technologies are available, or are currently under development, to control cow feeding in pasture-based dairy farms. Hills et al. [34] identified virtual fencing and 
individualized feeding as suitable technologies to implement precise feeding of grazing cows in pasture-based systems. The main idea behind these technologies is to provide cows with restricted access to resources based on their energy and nutritional needs to maximize the marginal response of cows to feed, so that the farm system is more efficient. In a virtual fencing system, cows with low $\mathrm{ME}_{\mathrm{t}}$ requirements can be grouped and given access to herbage of lower ME, while cows requiring higher energy levels can be allocated to herbage of higher energy content. Under individualized feeding, cows with higher MEt estimated requirements could potentially be fed more ME than lower MEt estimated requirements cows, leading to a more efficient use of ME. Such approach could be further enhanced if data on the genetic merit for milk production of individual cows were used to inform individual feeding. Cows of high genetic merit partition more energy towards milk and less towards body tissue than low genetic merit cows [35], and thus, their milk production response to supplements is relatively low [36]. Savings of feed should be expected if the genetic merit of cows is considered for the decision of allocating feed individually, as less feed could be potentially allocated to high genetic merit cows without altering milk production. Moreover, recent research by Fischer et al. [37] proved that restricting dry matter intake of cows that are less efficient compared to cows that are more efficient in converting feed and milk energy can significantly narrow the differences between cows, suggesting that overconsumption could be a driver of inefficiency and that controlling it could be a suitable strategy for reducing methane emissions without altering productivity of dairy farms.

\section{Conclusions}

This study found that the deviation of the daily $\mathrm{ME}_{\mathrm{t}}$ estimated requirements of a cow from the actual ME supplied per cow in the herd varied greatly and that such variation was mostly explained by the observations made within a cow rather than between cows or breeds. Having accurate estimates of daily $\mathrm{ME}_{\mathrm{t}}$ requirements of individual cows, in addition to proximal hyperspectral sensing measurements of herbage ME can potentially improve the efficiency of the pasture-based dairy farm by devising feeding strategies aimed at reducing DME and allowing a more precise fit between supply and demand for feed. However, for such information to be useful, changes to the farm system are most likely to be required. The data presented in this study provides empirical evidence that could be useful to determine the potential of individualized feeding strategies in pasture-based dairy farm systems. Future experimental research is required to test the effects of implementing feeding strategies designed to reduce DME on the physical, economic and environmental performance of pasture-based dairy farms.

Author Contributions: Conceptualization, F.D., N.L.-V. and S.M.; methodology, F.D. and N.L.-V.; software, F.D.; validation, F.D. and N.L.-V.; formal analysis, F.D. and N.L.-V.; investigation, F.D. and N.L.-V.; resources, N.L.-V., N.S., I.D., I.Y. and S.M.; data curation, F.D.; writing—original draft preparation, F.D.; writing—review and editing, N.L.-V., N.S., I.D., I.Y. and S.M.; visualization, F.D.; supervision, N.L.-V., N.S., I.D., I.Y. and S.M.; project administration, N.L.-V., N.S., I.Y. and S.M; funding acquisition, N.L.-V., N.S., I.Y. and S.M. All authors have read and agreed to the published version of the manuscript.

Funding: This research received no external funding.

Institutional Review Board Statement: Not applicable.

Informed Consent Statement: Not applicable.

Data Availability Statement: The data presented in this study are available on request from the corresponding author.

Acknowledgments: The authors would like to thank farm manager Jolanda Amoore and research technicians at Dairy 1, Massey University.

Conflicts of Interest: The authors declare no conflict of interest. 


\section{References}

1. Holmes, C.W. Milk Production from Pasture, 2nd ed.; Massey University: Palmerston North, New Zealand, 2002.

2. Nicol, A.M.; Brookes, I.M. The metabolisable energy requirements of grazing livestock. In Pasture and Supplements for Grazing Animals; Rattray, P.V., Brooks, I.M., Nicol, A.M., Eds.; New Zealand Society of Animal Production: Hamilton, New Zealand, 2007; Volume 14, pp. 151-172.

3. Waghorn, G. What is dietary metabolisable energy? Proc. N. Z. Grassl. Assoc. 2007, 69, 153-159. [CrossRef]

4. Tozer, P.; Bargo, F.; Muller, L. The effect of pasture allowance and supplementation on feed efficiency and profitability of dairy systems. J. Dairy Sci. 2004, 87, 2902-2911. [CrossRef]

5. Bargo, F.; Muller, L.; Delahoy, J.; Cassidy, T. Performance of high producing dairy cows with three different feeding systems combining pasture and total mixed rations. J. Dairy Sci. 2002, 85, 2948-2963. [CrossRef]

6. Shalloo, L.; Donovan, M.O.; Leso, L.; Werner, J.; Ruelle, E.; Geoghegan, A.; Delaby, L.; O’Leary, N. Review: Grass-based dairy systems, data and precision technologies. Animals 2018, 12, s262-s271. [CrossRef]

7. French, P.L.; O'Brien, B.; Shalloo, L. Development and adoption of new technologies to increase the efficiency and sustainability of pasture-based systems. Anim. Prod. Sci. 2015, 55, 931-935. [CrossRef]

8. Bargo, F.; Muller, L.; Kolver, E.; Delahoy, J. Invited review: Production and digestion of supplemented dairy cows on pasture. J. Dairy Sci. 2003, 86, 1-42. [CrossRef]

9. Macciotta, N.P.; DiMauro, C.; Rassu, S.P.; Steri, R.; Pulina, G. The mathematical description of lactation curves in dairy cattle. Ital J. Anim. Sci. 2011, 10, 213-223. [CrossRef]

10. Richard, D.; Guérin, H.; Fall Touré, S. Feeds of the dry tropics (Senegal). In Ruminant Nutrition: Recommended Allowances and Feed Tables; Jarrige, R., Ed.; John Libbey Eurotext: Montrouge, France, 1989.

11. Alderman, G.; Cottrill, B.R.; AFRC Technical Committee on Responses to Nutrients. Energy and Protein Requirements of Ruminants. An Advisory Manual Prepared by the AFRC Technical Committee on Responses to Nutrients; CAB international: Wallingford, UK, 1993.

12. National Research Council. Nutrient Requirements of Dairy Cattle; National Research Council: Washington, DC, USA, 2001.

13. Yan, T.; Agnew, R.; Murphy, J.; Ferris, C.; Gordon, F. Evaluation of different energy feeding systems with production data from lactating dairy cows offered grass silage-based diets. J. Dairy Sci. 2003, 86, 1415-1428. [CrossRef]

14. Tedeschi, L.O.; Cavalcanti, L.F.L.; Fonseca, M.A.; Herrero, M.; Thornton, P.K. The evolution and evaluation of dairy cattle models for predicting milk production: An agricultural model intercomparison and improvement project (AgMIP) for livestock. Anim. Prod. Sci. 2014, 54, 2052-2067. [CrossRef]

15. Auldist, M.J.; Wright, M.M.; Marett, L.C.; Hannah, M.C.; Kennedy, E.; Jacobs, J.L.; Wales, W.J. Milk production of cows grazing pasture supplemented by a partial mixed ration with or without canola meal. Anim. Prod. Sci. 2019, 59, 778-786. [CrossRef]

16. Heard, J.W.; Doyle, P.T.; Francis, S.A.; Staines, M.V.H.; Wales, W.J. Calculating dry matter consumption of dairy herds in Australia: The need to fully account for energy requirements and issues with estimating energy supply. Anim. Prod. Sci. 2011, 51, 605-614. [CrossRef]

17. Doyle, P.T.; Francis, S.A.; Stockdale, C.R. Associative effects between feeds when concentrate supplements are fed to grazing dairy cows: A review of likely impacts on metabolisable energy supply. Aust. J. Agric. Res. 2005, 56, 1315-1329. [CrossRef]

18. Handcock, R.; Lopez-Villalobos, N.; McNaughton, L.; Back, P.; Edwards, G.; Hickson, R. Positive relationships between body weight of dairy heifers and their first-lactation and accumulated three-parity lactation production. J. Dairy Sci. 2019, 102, 4577-4589. [CrossRef]

19. Sanches, I.D. Hyperspectral Proximal Sensing of the Botanical Composition and Nutrient Content of New Zealand Pastures. Ph.D. Thesis, Massey University, Palmerston North, New Zealand, 2009.

20. Duranovich, F.N.; Yule, I.J.; Lopez-Villalobos, N.; Shadbolt, N.M.; Draganova, I.; Morris, S.T. Using proximal hyperspectral sensing to predict herbage nutritive value for dairy farming. Agronomy 2020, 10, 1826. [CrossRef]

21. Cosgrove, G.P.; Betteridge, K.; Thomas, V.J.; Corson, D.C. A sampling strategy for estimating dairy pasture quality. Proc. N. Z. Soc. Anim. Prod. 1998, 58, 25-28.

22. DairyNZ. Facts and Figures: A Quick Reference Guide for New Zealand Dairy Farmers; DairyNZ: Hamilton, New Zealand, 2017; Available online: https:/ / www.dairynz.co.nz/publications/dairy-industry/facts-and-figures/ (accessed on 10 January 2021).

23. Westwood, C.T.; Mulcock, H. Nutritional evaluation of five species of forage brassica. Proc. N. Z. Grassl. Assoc. 2012, 74, 31-38.

24. Bates, D.; Maechler, M.; Bolker, B.; Walker, S.; Christensen, R.H.B.; Singmann, H.; Dai, B.; Scheipl, F. Package 'lme4', Version 2.74; CRAN, R Foundation for Statistical Computing: Vienna, Austria.

25. Clark, D.; Phyn, C.; Tong, M.; Collis, S.; Dalley, D. A Systems comparison of once-versus twice-daily milking of pastured dairy cows. J. Dairy Sci. 2006, 89, 1854-1862. [CrossRef]

26. Tong, M.; Clark, D.; Cooper, C. Once-a-day milking: Possible and profitable? Proc. N. Z. Grassl. Assoc. 2002, 64, 33-37. [CrossRef]

27. Holmes, C.W.; Wilson, G.F.; Mackenzie, D.D.S.; Purchas, J. The effects of milking once-daily throughout lactation on the per-formance of dairy cows grazing on pasture. Proc. N. Z. Soc. Anim. Prod. 1992, 52, 13-16.

28. Litherland, A.J.; Lambert, M.G. Factors affecting the quality of pastures and supplements produced on farms. In Pasture and Supplements for Grazing Animals; Rattray, P.V., Brooks, I.M., Nicol, A.M., Eds.; New Zealand Society of Animal Production: Hamilton, New Zealand, 2007; Volume 14, pp. 81-96.

29. Pérez-Prieto, L.; Delagarde, R. Meta-analysis of the effect of pasture allowance on pasture intake, milk production, and grazing behavior of dairy cows grazing temperate grasslands. J. Dairy Sci. 2013, 96, 6671-6689. [CrossRef] [PubMed] 
30. McCarthy, S.; Hirst, C.; Donaghy, D.; Gray, D.; Wood, B. Opportunities to improve grazing management. Proc. N. Z. Grassl. Assoc. 2014, 76, 75-80. [CrossRef]

31. Silvestre, A.; Petim-Batista, F.; Colaço, J. The accuracy of seven mathematical functions in modeling dairy cattle lactation curves based on test-day records from varying sample schemes. J. Dairy Sci. 2006, 89, 1813-1821. [CrossRef]

32. Brotherstone, S.; White, I.M.S.; Meyer, K. Genetic modelling of daily milk yield using orthogonal polynomials and parametric curves. Anim. Sci. 2000, 70, 407-415. [CrossRef]

33. Ingvartsen, K.L.; Andersen, J.B. Integration of metabolism and intake regulation: A Review focusing on periparturient animals. J. Dairy Sci. 2000, 83, 1573-1597. [CrossRef]

34. Hills, J.L.; Rawnsley, R.P.; Harrison, M.T.; Bishop-Hurley, G.J.; Henry, D.A.; Raedts, P.; Freeman, M.; Roche, J.R. Precision feeding and grazing management for temperate pasture-based dairy systems. In Proceedings of the Conference on Precision Dairy Farming 2016, Leeuwarden, The Netherlands, 21-23 June 2016; pp. 25-31.

35. Agnew, R.; Yan, T. Impact of recent research on energy feeding systems for dairy cattle. Livest. Prod. Sci. 2000, 66, 197-215. [CrossRef]

36. Kennedy, J.; Dillon, P.; Delaby, L.; Faverdin, P.; Stakelum, G.; Rath, M. Effect of genetic merit and concentrate supplementation on grass intake and milk production with holstein friesian dairy cows. J. Dairy Sci. 2003, 86, 610-621. [CrossRef]

37. Fischer, A.; Edouard, N.; Faverdin, P. Precision feed restriction improves feed and milk efficiencies and reduces methane emissions of less efficient lactating Holstein cows without impairing their performance. J. Dairy Sci. 2020, 103, 4408-4422. [CrossRef] [PubMed] 